\title{
REPRESENTAÇÕES DA MONARQUIA CONSTITUCIONAL NO ESPAÇO PÚBLICO PORTUGUÊS (1880-1910)
}

\section{REPRESENTATIONS OF CONSTITUTIONAL MONARCHY ON PORTUGUESE PUBLIC SPHERE (1880-1910)}

\author{
Teresa Nunes \\ Universidade de Lisboa
}

SUMARIO: I. INTRODUÇÃO.- II. D. LUÍS, O TRICENTENÁRIO CAMONIANO E OS OLHARES SOBRE A MONARQUIA CONSTITUCIONAL NO ESPAÇO PÚBLICO. III. S.P.Q.R. - SENHOR, O POVO QUER REPÚBLICA. - IV. DO ENGRANDECIMENTO DO PODER REAL AO OCASO DA MONARQUIA CONSTITUCIONAL PORTUGUESA: O REI E O ESPAÇO PÚBLICO. - V CONSIDERAÇÕES FINAIS

Resumo: Em 1851 iniciava-se a Regeneração, uma nova fase da vida política portuguesa conotada com o esforço de modernização económica e estabilização social do país. A concretização desses objectivos determinava mudanças no enquadramento constitucional, em especial nas atribuições do rei. Neste artigo apresenta-se uma análise sobre a forma como evoluiu a representação pública da figura régia entre o Centenário Camoniano de 1880 e a implantação do regime republicano, em Outubro de 1910.

Abstract: In 1851, Regeneração, a new phase on Portuguese political life associated with the efforts of national economic modernization and social pacification, began. Achieving those objectives determined changes on constitutional framework, especially on king's competences. In this article, an analisys is presented on the evolution of king's public representation since 1880 Camonian Centenary until the implementation of republic regime in October 1910.

Palavras chave: Rei, Monarquia Constitucional, República, Espaço Público Português, representação política

Key Words: King, Constitutional Monarchy, Republic, Portuguese Public Sphere, Political Representation

\section{INTRODUÇÃO}

A implantação do liberalismo em Portugal, em 1820, representou o início de um longo e amplo debate, não raras vezes de natureza sangrenta, sobre o papel do monarca no contexto institucional concebido à luz dos princípios da soberania da nação e da separação de poderes. Objecto de reflexão em momento anterior, mormente no decurso do reinado de D. Maria I, o assunto adquiria particular 
relevância no âmbito das Cortes Gerais e Extraordinárias e Constituintes de 1821 , as quais produziam o primeiro texto constitucional português. Definido como "inviolável"1, desprovido de responsabilidade e dotado de autoridade "inalienável", emanada da nação ${ }^{2}$, o rei, na asserção vintista ${ }^{3}$, inscrevia-se numa estrutura institucional encimada pelo Poder Legislativo, a representante da nação livre e independente, responsável pelas leis fundamentais que dispensavam sanção real. A perspectiva vintista avultava tão mais relevante quanto os legisladores consideravam indispensável a consagração dos poderes do rei $^{4}$ como a consignação de quanto se encontrava interdito à figura régia ou ao alcance da mesma, sob a tutela das cortes ${ }^{5}$.

Agente soberano, por delegação das Cortes Gerais, ao rei ficava incumbido o poder executivo, prevalecendo uma concepção patriarcal subjacente à presidência do governo. Nas palavras do constituinte Castelo Branco, o rei "é como um pai que deve espalhar todos os beneficios possiveis sobre todos os individuos da grande monarquia portuguesa. A soberania reside na nação inteira: todos os cidadãos devem ter parte no exercício de soberania, mas não sendo possivel que todos a exercitem" . Logo reconfigurado à luz do texto constitucional, o monarca adquiria um estatuto de imprescindibilidade, assente nas dinâmicas do sistema representativo e respectivos patamares de intermediação entre a fonte primordial de soberania, o povo, e o legislador, seu representante.

Nas análises críticas desenvolvidas sucessivamente por António Manuel Pereira $^{7}$, Marcelo Caetano ${ }^{8}$ e Jorge Miranda ${ }^{9}$, incidentes sobre os textos constitucionais portugueses, evidenciavam a prevalência de idêntico

\footnotetext{
1 Constituição Politica da Monarquia Portuguesa decretada pelas Cortes Gerais Extraordinárias e Constituintes reunidas em Lisboa, no Ano de 1821, Lisboa, Imprensa Nacional, 1822 , p. 54.

2 Constituição Politica da Monarquia Portuguesa decretada pelas Cortes Gerais e Extraordinárias e Constituintes, op. cit., p. 15.

3 Designação alusiva à Constituição de 1822. Ana Maria Pina, De Rousseau ao imaginário da Revolução de 1820, Lisboa, Instituto Nacional de Investigação Científica, 1988.
}

4 Constituição Política da Monarquia Portuguesa decretada pelas Cortes Gerais e Extraordinárias e Constituintes, op. cit., p. 51.

5 Artigo 124. O Rei não pode: I Impedir as eleições dos Deputados, opor-se à reunião das Cortes; prorrogá-las, dissolvê-las ou protestar contra as suas decisões; II Impor tributos, contribuições ou fintas; III Suspender majistrados excepto nos termos do artigo 197; IV Mandar prender cidadão excepto: $1^{\circ}$ quando o exigir a segurança do Estado, devendo o preso ser entregue ao juiz competente em 48 horas; $2^{\circ}$ quando as Cortes tenham suspendido as formalidades judiciais; V Alienar porção alguma do território nacional; VI Comandar a força armada. Artigo 126 O Rei não pode, sem consentimento das Cortes: I Abdicar da Coroa; II Sair do Reino de Portugal e Algarves e, se o fizer, se entenderá que abdica; bem como se havendo saído com licença das Cortes, a exceder quanto ao tempo ou lugar e não regressar ao Reino quando chamado. A diposição é aplicável ao sucessor da Coroa; III Tomar empréstimo em nome da Nação". Constituição Política da Monarquia Portuguesa decretada pelas Cortes Gerais e Extraordinárias e Constituintes, op. cit., pp. 52-53.

6 Diário das Cortes Constituintes, sessão n 10, 9 de Fevereiro de 1822, p. 136.

7 António Manuel Pereira, As Constituições Politicas Portuguesas, Porto, A.M. Pereira, 1961.

8 Marcelo Caetano, Constituições Portuguesas, 4ª ed. actualizada, Lisboa, Verbo, 1978.

9 Jorge Miranda, As Constituições Portuguesas: 1822, 1838, 1911, 1933, 1974, Lisboa, Petrony, 1976. 
posicionamento articular do rei, axial entre a fonte de soberania e o poder legislativo, no decurso das opções assumidas pelos Setembristas em 1838. Observando um parâmetro tendencialmente mitigado, conforme os ensejos de conciliação entre as premissas da Constituição Vintista e as orientações da Carta Constitucional, a Constituição de Setembro previa a inviolabilidade do rei ${ }^{10}$ a quem cabia o poder executivo. Concomitantemente, o documento de 1838 encontrava utilidade em, à semelhança do demonstrado em 1822, estabelecer expressamente os limites da actuação régia ${ }^{11}$ bem como os actos para os quais as Cortes eram chamadas a dar anuência ${ }^{12}$.

Eivada de premissas basilares diferenciadas, a Carta Constitucional de 29 de Abril de 1826, recuperada em 1842 e mantida até Outubro de 1910, redefinia a natureza do Estado português, um exercício concebido à luz de um alcance revisitado de soberania nacional, na esteira das tendências do constitucionalismo observadas na conjuntura europeia dos primórdios de Oitocentos. A arquitectura institucional concebida por D. Pedro IV de Portugal reposicionava a figura régia, objecto de um engrandecimento multidimensional, na vida política nacional. Ao monarca, assim reconhecido "por graça de Deus" ${ }^{13}$, incumbia a centralidade do sistema construído para conservar os "direitos dos cidadãos" e, simultaneamente "o meio seguro de fazer efectivas as garantias que a Constituição oferece"14.

A fórmula de tripartição do poder cedia perante a emergência do denominador poder moderador, caracterizado como "a chave de toda a organização política" ${ }^{15}$. Competência privativa do Rei, retratado igualmente como o "chefe supremo da nação"16, a novel dimensão fundava-se na necessidade de uma vigilância constante e perene, capaz de assegurar a harmonia desejável entre os mais pilares do Estado. Ora reconfigurado em guardião do sistema constitucional, a Pessoa Real mantinha o carácter sagrado e inviolável reconhecido pela Constituição de 1822 (e posteriormente pelo texto de 1838), valências indispensáveis para o cumprimento integral das exigências requeridas em 1826 a saber, a nomeação dos Pares do Reino, sem limitação de número; a p. 18 .

10 Artigo 85, Constituição Política da Monarquia Portuguesa, Lisboa, Imprensa Nacional, 1838,

11 “Artigo 83 O Rei não pode: I impedir a eleição de deputados ou senadores; II Opor-se à reunião das cortes no dia 2 de Janeiro de cada ano; III nomear em tempo de paz comandante em chefe para o exército ou armada; IV comandar a força armada ou nomear para comandante em chefe o principe real ou infantes; V perdoar ou minorar as penas aos ministros e secretários de estado por crimes cometidos no exercício das suas funções". Constituição Politica da Monarquia Portuguesa, op. cit., , p. 17-18.

12 "Artigo 84 O Rei não pode também, sem o consentimento das Cortes: I Ser ao mesmo tempo chefe de outro Estado; II Sair do Reino de Portugal e Argarves, e se o fizer, entende-se que abdica”. Constituição Política da Monarquia Portuguesa, op.cit., p. 18.

13 Carta Constitucional da Monarquia Portuguesa decretada e dada pelo Rei de Portugal e Algarves, D.Pedro do Brasil, aos 29 de Abril de 1826, Lisboa, Imprensa Régia, 1827, p. 5.

14 Carta Constitucional da Monarquia Portuguesa decretada e dada pelo Rei de Portugal, op. cit., p. 5.

15 Carta Constitucional da Monarquia Portuguesa decretada e dada pelo Rei de Portugal, op. cit., Artigo 71, p. 16.

16 Carta Constitucional da Monarquia Portuguesa decretada e dada pelo Rei de Portugal, op. cit., Artigo 71, p. 16. 
convocação de Cortes Gerais extraordinárias, nos intervalos das sessões, caso assim imponha o "Bem da Nação"; a sanção dos decretos e resoluções das Cortes Gerais para que adquiram força de lei; a prorrogação ou adiamento das Cortes Gerais e a dissolução da Câmara dos Deputados, "nos casos em que o exigir a Salvação do Estado", mediante a convocação de substituto; a nomeação ou demissão livre dos ministros; a suspensão dos magistrados em situação previamente definida; o perdão ou moderação das penas impostas aos réus sentenciados; por último, a concessão de amnistia em condição de urgência "quando assim o aconselhe a Humanidade e o Bem do Estado" .

As novas funções reservadas à Pessoa Real, de complexidade inequívoca aferida a relação respectiva com o regular funcionamento das duas câmaras do Poder Legislativo e com as magistraturas, não iludiam as velhas obrigações do monarca, em quem a Constituição Política de 1822 depositava o Poder Executivo, uma escolha igualmente assumida na Carta Constitucional. Observe-se, porém, que esta similitude de orientações sobre a governação do Estado não representava meramente um factor de continuidade, considerado o leque alargado de atribuições régias, instituído em 1826.

Segundo a fórmula ulterior, ao Rei, chefe do Poder Executivo, incumbia observar as realidades seguintes: convocar cortes gerais ordinárias no quarto ano da legislatura em vigor no contexto metropolitano (no ano antecedente, no espaço colonial); nomear os bispos e prover os beneficios eclesiásticos; designar os magistrados; prover os empregos civis e politicos; designar os comandantes militares das forças terrestres e maritimas e proceder à respectiva exoneração, conforme o "bem do Estado"; conduzir a politica externa portuguesa: dirigir negociações com as potências estrangeiras, estabelecer alianças e tratados (de amizade, militares, comerciais, outras), submetendo-os ao conhecimento das Cortes Gerais, também designadas de Assembleia, após a conclusão respectiva e em momento oportuno ao interesse do Estado; declarar a guerra e fazer a paz, com posterior comunicação à Assembleia das comunicações compativeis com os interesses e a segurança nacional.

Por outro lado, cabia-lhe conceder a naturalização, por intermédio da emissão de cartas; atribuir títulos, honras, ordens militares e distinções por recompensa de serviços prestados ao Estado; expedir decretos, instruções e regulamentos inerentes à regular execução das leis, decretar a aplicação das verbas aprovadas pelas Cortes Gerais à administração do Estado; conceder ou recusar o beneplácito a documentos dos concílios e letras apostólicas, precedendo a aprovação das Cortes Gerais; prover à segurança interna e externa do Estado, conforme prescrito no texto constitucional ${ }^{18}$.

A natureza do poder reconhecido ao monarca constitucional, de origem divina, a amplitude das funções adstrictas ao poder executivo e, concomitantemente, a centralidade subjacente ao poder moderador, actuante como agente de estabilização constante do sistema político, era inconciliável com a prevalência de itens proscritos à Figura Real. Das proibições formais elencadas

17 Carta Constitucional da Monarquia Portuguesa decretada e dada pelo Rei de Portugal, op. cit., Artigo 74, pp. 16-17.

18 Carta Constitucional da Monarquia Portuguesa decretada e dada pelo Rei de Portugal, op. cit., Artigo 75, pp. 17-18. As mercês pecuniárias ficavam sujeitas à aprovação das Cortes Gerais. 
nas constituições de 1822 e 1838, subsistia o impedimento de saída do reino, sem aprovação prévia das Cortes Gerais e a conotação de tal acto com a abdicação da coroa ${ }^{19}$. No mesmo passo, estranhamente ou talvez não, mantinhase inalterável o texto do juramento real - "juro manter a religião católica apostólica romana, a integridade do reino, observar a constituição política da nação portuguesa e mais leis do Reino e prover ao bem geral da nação, quanto em mim couber" - consagrado pela experiência liberal vintista e, consequentemente, desfasada do enquadramento instituído em $1826^{20}$.

Em 1851, encetava-se um novo ciclo político sob a égide da Regeneração, conceito estruturante do ideário liberal português oitocentista. Alcançar a pacificação interna, no rescaldo da experiência governativa desenvolvida por António Bernardo da Costa Cabral, entre 1842 e 185121, da Guerra Civil da Patuleia, de 1846 a 1847 bem como do impacto da Convenção de Gramido ${ }^{22}$, revelava-se um momento redefinidor das estruturas institucionais, mormente do perímetro de actuação previsto para o rei. O Acto Adicional à Carta Constitucional de $1852^{23}$ inscrevia uma alteração profunda na condução da politica externa, obrigando à aprovação de qualquer tratado, concordata ou convenção com potências estrangeiras pelas Cortes Gerais, antes da ratificação, em sessão secreta ${ }^{24}$. A excepcionalidade prevista na redacção de 1826, subordinada a acordos entre potências celebrados em tempo de paz, expressa ou indirectamente relacionados à cessão ou troca territorial ${ }^{25}$, transformava-se em norma preceitual aplicável a quaisquer acordos celebrados pelo Estado Português.

O debate sobre a modernização do sistema político, constante na segunda metade do séc. XIX, conhecia uma nova fase em meados da década de 80. Em Julho de 1885, um novo Acto Adicional à Carta comportava mudanças substanciais as quais reflectiam consequências relevantes na articulação entre os quatro poderes. Observe-se, em especial, a limitação do número de membros da câmara dos Pares, circunstância que induzia um recuo da intervenção régia no contexto legislativo ${ }^{26}$.

19 Carta Constitucional da Monarquia Portuguesa decretada e dada pelo Rei de Portugal, op. cit., Artigo 77, p. 19.

20 A persistência da fórmula vintista não passava despercebida à análise crítica de Trindade Coelho, nos primórdios do séc. XX; segundo o autor, de convicções republicanas, era revelador da disparidade entre o discurso político e a natureza do regime monárquico português. Trindade Coelho, Manual Politico do Cidadão Português, Lisboa, Parceria A..M. Pereira, 1906, pp. 495-515.

21 Maria de Fátima Bonifário, A Segunda Ascensão e Queda de Costa Cabral 1847-1851, Lisboa, ICS, 2002.

22 Teresa Nunes, Maria da Fonte e Guerra Civil da Patuleia 1846-1847, Matosinhos, QuidNovi, 2008.

23 Acto Adicional à Carta Constitucional Julho de 1852.

24 Acto Adicional à Carta Constitucional, Artigo 10. A opção aprovada em 1826 conferia ampla margem de decisão conferia ampla actuação no dominio da politica externa.

25 Carta Constitucional da Monarquia Portuguesa decretada e dada pelo Rei de Portugal, op. cit., Artigo 75, pp. 17-18

26 Acto Adicional. Lei de 24 de Julho de 1885. Apenso à Carta Constitucional. Artigo 6. Segundo o documento, a Câmara dos Pares ficava limitada a cem membros, de nomeação régia. 
Esta fórmula vigorava até Setembro de 1896, tendo então sido objecto de reforma pelo terceiro, e último, acto adicional à Carta, no séc. XIX. Acentuava-se a tendência de decréscimo da Câmara dos Pares, através de nova redução de membros, e recentravam-se o exercício e as atribuições adstritas ao Poder Moderador. De acordo com o artigo 6, a partir de então, o exercício do quarto poder cabia ao rei, "com a responsabilidade dos ministros". O perímetro da actuação régia inscrevia-se nos seguintes moldes: promulgação de decretos, com força legislativa, nos casos previstos; designação dos Pares do Reino em número não superior a 90; prorrogação ou adiamento das Cortes Gerais, com dissolução da Câmara dos Deputados, convocando outra para substituição; perdão ou moderação das penas impostas aos réus condenados por sentença, à excepção de titulares do governo sentenciados por actos praticados no decurso das funções executivas $^{27}$.

Assim, de forma paulatina, a monarquia constitucional portuguesa procurava parcialmente corresponder às mutações observadas no contexto político e partidário nacionais como acompanhar as mudanças sociais operadas no mesmo período ${ }^{28}$. Por um lado, em meados da década de 70 , verificava-se uma diversificação das correntes ideológicas presentes no debate político, mormente com a presença crescente do republicanismo, do socialismo e, posteriormente, anarquismo. Por outro, a materialização dos desígnios subjacentes ao Estado Liberal induzia a uma alteração profunda das relações entre poderes, central e local, como entre governantes e governados ${ }^{29}$.

Por último, a inserção gradual da economia portuguesa nos contextos europeu e mundial, patente na multiplicação de tratados de comércio e navegação com potências estrangeiras a aumento dos fluxos comerciais com o exterior ${ }^{30}$, integrava as estruturas produtivas no perímetro das flutuações comerciais comuns no período cronológico em apreço ${ }^{31}$. As repercussões do fenómeno citado contribuíram para uma modificação substantiva dos parâmetros reivindicativos endógenos, os quais reflectiam as alterações no mercado interno ${ }^{32}$ e os consequentes surtos migratórios, com destinos diferenciados em função das disponibilidades financeiras dos imigrantes ${ }^{33}$.

Uma das características estruturantes das décadas de 80 e 90 do séc. XIX apreciava-se no crescimento da densidade demográfica dos grandes centros

${ }^{27}$ Acto Adicional à Carta Constitucional de 25 de Setembro de 1896, Artigo 6.

28 Maria de Fátima Bonifácio, Monarquia Constitucional 1807-1910, Alfragide, Texto, 2010.

29 Pedro Tavares de Almeida, A Construção do Estado Liberal: Elite Política e Burocracia da Regeneração (1851-1890). Tese de doutoramento, Lisboa, Universidade Nova de Lisboa, 1995.

30 Miriam Halpern Pereira, Livre-Câmbio e Desenvolvimento Económico. Portugal na segunda metade do séc. XIX, Lisboa, Cosmos, 1971; Pedro Lains, A Economia Portuguesa no séc. XIX, Lisboa, INCM, 1995.

31 Teresa Nunes, "A Espanha na Diplomacia Comercial Portuguesa na Segunda Metade do Séc. XIX e o Tratado de Comércio e Navegação de 1893",História[online]. 2017, vol.36, e14. Epub Aug 17, 2017. ISSN 1980-4369. http://dx.doi.org/10.1590/1980-436920170000000014.

32 David Justino, A Formação do Espaço Espaço Económico Nacional, 2 vols, Lisboa, Vega, 1989.

33 Miriam Halpern Pereira, A Política Portuguesa de Emigração (1850-1930), Lisboa, A Regra do Jogo, 1981. 
urbanos, Lisboa e Porto. Decerto, este fenómeno resultava do aumento

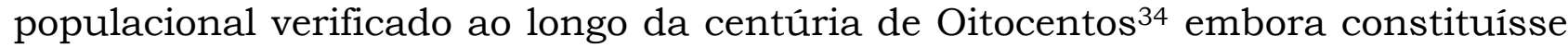
igualmente o reflexo inequívoco da afluência de populações desapossadas de meios de subsistência nas áreas rurais pelos processos de modernização ou mudança das dinâmicas produtivas do sector agrícola. Desprovido de recursos financeiros para abandonar o país, este fluxo era comummente constituido por indivíduos de escassa ou nula alfabetização, nos quais o distanciamento geográfico do local de origem induzia fenómenos de desprotecção social e desenraizamento cultural. Quanto possivel, adaptavam-se às vivências do labor industrial, acomodavam-se às rotinas do enquadramento citadino e reconfiguravam os padrões de sociabilidade afeitos ao ambiente urbano ${ }^{35}$, enfileirando nos estratos de baixo rendimento e dando expressão à pobreza crescente, mormente na cidade de Lisboa.

As mudanças ocorrida no tecido económico nacional e nas estruturas sociais das grandes urbes portuguesas constituíam uma realidade ambivalente, a breve trecho apreendida pelas correntes ideológicas contestárias do enquadramento liberal português. Alvo dilecto da propaganda dos sectores anti-monárquicos republicanos, socialistas e anarquistas - este universo populacional urbano impulsionava a feitura de um discurso construído na senda das características imanentes do destinatário. Longe de constituir uma dimensão unilateral, a representação e mobilização politica dos mais desfavorecidos implicava o recurso a uma metodologia de intervenção pública concebida através da identificação dos interesses, das motivações e da capacidade de reacção dos grupos sociais a enquadrar. A prossecução de tais critérios determinava um reposicionamento da actuação política dos sectores anti-monárquicos, concebido à luz da necessária proximidade estabelecida com a população urbana ${ }^{36}$. Consequentemente, procedia-se à redefinição dos tópicos de maior visibilidade na propaganda antimonárquica, acompanhada da simplificação do discurso concebido em parâmetros simultaneamente maniqueístas e imediatistas ${ }^{37}$. Já a composição formal da mensagem politica acompanhava a tendência e observava alterações sintomáticas do paradigma de actuação no contexto eminentemente citadino.

A partir da década de 90 do séc. XIX, republicanos e socialistas pontificavam activamente neste processo de transformação radical de discursos e práticas políticas. Tratava-se, porém, de uma investida anti-monárquica caracterizada pela ampla rivalidade entre os dois grupos supramencionados, uma concorrência que induzia a um acréscimo suplementar da agressividade, explícita ou tácita,

\footnotetext{
34 Teresa Rodrigues (Coord.), História da População Portuguesa. Das longas permanências à conquista da modernidade, Porto, Cepese/Afrontamento, 2009.

35 Maria João Vaz, Crime e Sociedade: Portugal na segunda metade do séc. XIX, Oeiras, Celta, 1998.

36 Amadeu Carvalho Homem, A Propaganda Republicana (1870-1910), Coimbra, Coimbra Editora, 1990.

37 Ernesto Castro Leal, Manifestos, Estatutos e Programas Republicanos Portugueses, Lisboa, INCM, 2014.
} 
das mensagens produzidas neste contexto prevalecente até à queda da monarquia em Portugal ${ }^{38}$.

Contudo, o período revelava-se igualmente pródigo em alterações significativas no espectro partidário anti-liberal. Entidade presente e participativa no decurso da segunda metade do séc. XIX, o Partido Legitimista assomava com vigor renovado no decurso do Ultimatum Inglês (1890) e da crise financeira que assolou Portugal nos anos imediatamente subsequentes (1891-1893). Reivindicando, tal como republicanos e socialistas, a responsabilidade de conduzir o resgate da nação em perigo, os Legitimistas não hesitavam em subscrever as tendências em voga na época e modernizar os padrões de intervenção respectiva através da feitura e divulgação de conteúdos programáticos no órgão de imprensa próprio, A Nação.

Assente na preservação dos princípios e dos valores estruturantes da realidade portuguesa, o programa legitimista almejava uma influência renovada nos sectores rurais, tendencialmente reconhecidos como conservadores. No caso vertente, a concepção de conteúdos programáticos, prática antes ausente das dinâmicas intrinsecas à referida formação, visava as politicas liberais como promotoras da desagregação social e empobrecimento generalizado do país. Segundo o articulado preambular, o modelo liberal era incompatível com as lógicas de organização intrínsecas à sociedade portuguesa e inconciliável com o quadro de referências, culturais e mentais, adoptado paulatinamente pela nação. À luz desta leitura, o desenvolvimento da riqueza nacional e a pacificação da sociedade significava o retorno a fórmulas tradicionais, desprovidas de conflitualidade endógena e de mecanismos de apropriação do Estado por interesses de grupos específicos em detrimento das necessidades dos segmentos demográficos com recursos económicos reduzidos ou nulos. Esses, longe de beneficiar com a legislação liberal, viam-se assolados pelas investidas do Estado Liberal sobre a propriedade fundiária conforme o disposto no Código Civil de $1867^{39}$ e disposições subsequentes sobre a modernização da produção agrícola portuguesa, implementadas por Emídio Navarro em 1887.

As mesmas dinâmicas de mudança da agricultura, por seu turno, viriam a ser entendidas como um atentado aos direitos de propriedade e, nessa medida, assumiam uma dimensão axiomática da crítica acérrima exercida por um conjunto apreciável de grandes proprietários rurais ao Estado Liberal. Congregado em torno de $A$ Época ${ }^{40}$, sob a égide do Visconde de Coruche, o director do periódico, e dos órgãos de imprensa sucessores, o Correio de Lisboa ${ }^{41}$

38 António Ventura, Anarquistas, Republicanos e Socialistas em Portugal. As Convergências Possiveis (1892-1910), Lisboa, Cosmos, 2000.

39 António Manuel Hespanha, Guiando a Mão Invisível. Direitos, Estado e Leis no Liberalismo Monárquico Português, Coimbra, Almedina, 2004, p. 464.

40 A Época. Órgão da Agricultura Portuguesa, iniciado em 8 de Novembro de 1886 [data do número-programa], publicou-se regularmente até 30 de Abril de 1892. Dirigido por Visconde de Coruche, seu fundador, contou com a colaboração de Artur Lobo de Ávila, D.José de Alarcão, Leonardo Torres, Visconde Moreira del Rey e Barão das Lages.

41 O Correio de Lisboa teve publicação regular entre 30 de Abril de 1892 e 5 de Agosto de 1898. Registou colaboração de autores diversos como o Visconde de Coruche, Nemo, José Veríssimo de Almeida. Assumindo a continuidade de objectivos e colaboradores, poderemos deduzir que não tenha havido grande alteração face ao elenco de participantes regulares de A Época. Contudo, a 
e, por último, no Correio Agrícola de Lisboa ${ }^{42}$, o grupo sublinhava os perigos subjacentes à inserção económica do país no contexto alargado. Particularizava especialmente as políticas alfandegárias incidentes sobre a produção cerealífera, as limitações aplicadas às culturas do arroz e do tabaco, a inoperância do Estado Liberal na resolução dos problemas associados à vinha e à exportação de vinhos. Não menos relevante, nas páginas dos periódicos espraiava-se a censura às iniciativas preconizadas pelos sucessivos ministros das Obras Públicas, Comércio e Indústria na simplificação das formas de propriedade, na alteração da estrutura fundiária e no acréscimo de fiscalidade sobre a terra.

No pensamento de Coruche estabelecia-se uma correlação estreita entre a defesa da pátria e a salvaguarda da propriedade, premissa basilar sobre o entendimento diferenciado acerca do sistema de representação política e da organização do Estado. Para o Autor, contrariar os efeitos desnacionalizantes do cosmopolitismo, materializados em Portugal pela presença de capitais estrangeiros e, não menos relevante, pela associação destes à religião judaica, significava a promoção de todos quantos dependiam única e exclusivamente da actividade produzida no país para sobrevivência respectiva, em tempos coevos e futuros. Deste raciocínio, extraía-se o protagonismo dos proprietários/agricultores, uma vertente por si só insuficiente, em vista da qualidade intrínseca à decisão política.

Alcançar esta pressupunha, por um lado, interditar aos cidadãos estrangeiros a aquisição de propriedade agrícola em Portugal e, por outro, promover a confluência entre o exercício da decisão política, a confissão cristã e o núcleo dos proprietários/agricultores de rendimentos mais elevados ${ }^{43}$. Se a riqueza constituía garante da independência do decisor e, por extensão, da salvaguarda do bem comum, a condição de proprietário/agricultor arreigava o conceito de soberania nacional ao primado da independência alimentar do país.

\section{D. LUÍS, O TRICENTENÁRIO CAMONIANO E OS OLHARES SOBRE A MONARQUIA CONSTITUCIONAL NO ESPAÇO PÚBLICO}

Do ponto de vista institucional, a década de 80 do séc. XIX principiava sob os auspícios do paradoxo. Decerto prenunciava a estabilização do sistema político português, consubstanciado na implementação do rotativismo entre dois partidos então considerados esteios basilares, a saber o Partido Regenerador, liderado por António Maria Fontes Pereira de Melo, e o Partido Progressista, chefiado por Anselmo Braamcamp Freire ${ }^{44}$.

circunstância de parte substancial dos textos não serem subscritos de forma inequívoca, impedem-nos a verificação cabal acerca da referida continuidade.

42 O Correio Agrícola de Lisboa. Periódico político-agrícola publicou-se a partir de 5 de Agosto de 1899 e 30 de Dezembro de 1906. Dirigido por João Maria Couto Brandão, teve a colaboração de D.Francisco de Noronha, o Conde de Bertiandos ou Nemo [Fernando de Sousa]. Afere-se ainda, segundo informação do jornal, a lógica de continuidade, circunstância que não poderemos atestar face ao grupo de colaboradores face à forma quase incógnita como os textos eram publicados.

43 Visconde de Coruche, "Novo Partido Nacional e o Mal Cosmopolita", A Época, no 727, 5 de Maio de 1889 , p. 1.

${ }^{44}$ Luís Espinha da Silveira, Paulo Jorge Fernandes, D.Luis I, Rio de Mouro, Temas e Debates, 2009, pp. 261-306. 
No entanto a assunção das dinâmicas de alternância resultava das denominadas "campanhas democráticas" contra o Rei D. Luís, preconizadas pelos Progressistas, no final dos anos 70. Em Janeiro de 1878, o Partido Progressista reagia pública e violentamente à circunstância de ter sido preterido na função executiva, em favor do Partido Regenerador. A acrimónia crescente inspirava uma campanha ampla na imprensa, naturalmente dirigida ao oponente político. Porém, os Progressistas não se quedavam na análise às características do governo regenerador e objectivos respectivos; antes visavam directamente o chefe de estado que, em razão das atribuições inerentes do Poder Moderador, projectavam como o exclusivo responsável por esta opção. As críticas formuladas em Janeiro do ano seguinte apresentavam a figura régia como "chefe de um bando político"45, empenhado em ocultar a contínua delapidação de recursos financeiros do país em prol da elite regeneradora.

Caracterizado o Paço Real como fonte de contaminação das estruturas institucionais do país, os progressistas alcançavam o paroxismo com o repto ao impeto revolucionário da plebe: o Partido Progressista manifestava-se disponível para liderar a revolução e implantar a república, caso D. Luís não acedesse a uma mudança do executivo ${ }^{46}$. O executivo regenerador, ciente do impacto público da campanha de descrédito das instituições monárquicas, através da reforma da lei do pariato e do alargamento substancial do sufrágio eleitoral, nos meses de Abril e Maio de 1878 respectivamente. O objectivo de Fontes Pereira de Melo consistia em rebater os argumentos esgrimidos nas propagandas dos partidos, progressista e republicano. Porém, os resultados obtidos pelo Partido Regenerador, em Lisboa e Porto, nas eleições de Outubro, ficavam aquém das expectativas do chefe do executivo que, em Junho de 1879, submetia o pedido de exoneração ao rei para estancar o perigo revolucionário.

Assim, a normalização da vida pública portuguesa decorria efectivamente mas sob o signo do desgaste da figura régia a qual, a breve trecho, era novamente posta à prova, no contexto das comemorações do Tricentenário Camoniano, realizadas em 10 de Junho de 1880 . Resultante do interesse renovado pela vida e obra de Luís Vaz de Camões, fruto da investigação e das publicações do Visconde de Juromenha entre 1860 e 186947, as comemorações reflectiam igualmente as análises desenvolvidas sobre o Poeta no decurso dos anos 70. Sublinhe-se os contributos de Francisco Evaristo Leoni ${ }^{48}$, de Joaquim Pedro de Oliveira Martins $^{49}$ e, particularmente, de Teófilo Braga 50 na reavaliação do significado subjacente ao percurso biográfico e labor poético de Camões.

\footnotetext{
${ }^{45}$ Maria de Fátima Bonifácio, O Seculo XIX português, Lisboa, Instituto de Ciências Sociais, 2002, p. 94.

${ }^{46}$ Basílio Teles, Do Ultimatum ao 31 de Janeiro: Esboço d'história política, Porto, Ed. Do Autor, 1905, p. 51.

${ }^{47}$ Visconde de Juromenha, Obras de Luís de Camões:precedidas de um ensaio biográfico no qual se relatam alguns factos da sua vida aumentadas com algumas composições inéditas do Poeta, 6 vols, Lisboa, Imprensa Nacional, 1860 1869.

${ }^{48}$ Francisco Evaristo Leoni, Camões e os Lusíadas: ensaio histórico-crítico, Lisboa, A.M.Pereira, 1872.

49 Joaquim Pedro de Oliveira Martins, Os Lusíadas. Ensaio sobre Camões e a sua obra em relação à sociedade portuguesa e ao movimento da Renascença, Porto, Imprensa Portuguesa, 1872.

${ }^{50}$ Teófilo Braga, História de Camões, 3 vols, Porto, Imprensa Portuguesa, 1873; Teófilo Braga, Os Novos Críticos de Camões, Porto, Imprensa Portuguesa, 1873.
} 
Observe-se as conotações politicas e ideológicas subjacentes aos trabalhos dados à estampa pelos autores referidos, com especial ênfase no caso do terceiro, cuja filiação republicana compelia a uma abordagem do Bardo enquanto emblemático da capacidade de sobrevivência, de resistência às dificuldades e da entrega à pátria51. Estas premissas, bem como a vontade expressa de Teófilo Braga de promover a figura de Camões como símbolo de uma nova era de conciliação, necessariamente laica e positivista, suscitavam as maiores apreensões do executivo progressista liderado por Anselmo Braamcamp Freire.

Em 17 de Maio de 1879, a Sociedade de Geografia de Lisboa anuía ao pedido de celebração do centenário, endereçado por Joaquim de Vasconcelos, o qual considerava a pertinência de uma cerimónia de carácter nacional caracterizada pela componente intstitucional e amplo contributo do público. Teófilo Braga retorquia ao projecto com a ideia de uma iniciativa exclusivamente nacional, em conformidade com a identificação antes expressa de Camões enquanto personalidade evocativa de pátria portuguesa. Esta abordagem comemorativa viria a consolidar-se entre os membros da comissão executiva do Centenário, designada a 8 de Abril de 1880. Conforme o entendimento formulado pelos membros - Eduardo Coelho, Luciano Cordeiro, Ramalho Ortigão, Rodrigues da Costa, Magalhães Lima, Batalha Reis, Manuel Pinheiro Chagas, Visconde de Juromenha e Teófilo Braga - pretendia-se alcançar mais do que uma mera realização de âmbito literário ou reproduzir o modelo exclusivamente oficial e solene, adoptado aquando da inauguração da estátua ao Bardo, em 1867. O objectivo do evento consistia em "explicar que, simbolizando a obra de Camões, o poder da individualidade portuguesa no concílio das nações modernas, deverá exprimir-se a consciência nacional desse poder como que a prova do espelho posto à boca do homem exânime para o fim de verificar se ele respira ou não"52.

Assim, muito embora a Comissão Executiva apresentasse uma composição política heterogénea - repartida entre as convicções absolutistas e o ideário republicano - a narrativa consensualmente aceite consubstanciava a correlação estreita entre o Bardo e a nação portuguesa, tributária da análise de Teófilo Braga. Acrescia o pudor da Comissão Executiva em solicitar directamente o patrocínio régio da iniciativa, circunstância entendida pelo governo progressista como forma oportuna de se retirar das comemorações. Recomendação idêntica seria reiterada à Casa Real que, no último momento, manifestava a adesão ao evento, assinalada com a presença da Família Real na tribuna ${ }^{53}$.

O Tricentenário Camoniano viria a revelar-se um momento de galvanização do ideário republicano no contexto público nacional; de igual modo, consolidava o empenhamento do Partido Republicano Português na defesa dos interesses nacionais em estrita consonância com a questão colonial e a salvaguarda do império, valências da propaganda republicana ensaiadas originalmente com as

\footnotetext{
51 Jorge Borges de Macedo, “Camões - Símbolo e Mito no séc. XIX Português: da erecção da estátua ao Trincentenário (1867-1880), História de Portugal, Coord. por João Medina, vol. VIII, Alfragide, Ediclube, 1993, pp. 321-344.

52 Jorge Borges de Macedo, “Camões - Símbolo e Mito no séc. XIX Português: da erecção da estátua ao Trincentenário (1867-1880), op. cit., p. 340.

53 Jorge Borges de Macedo, "Camões - Símbolo e Mito no séc. XIX Português: da erecção da estátua ao Trincentenário (1867-1880), op. cit., p. 341.
} 
manifestações contra a celebração do Tratado de Lourenço Marques, em finais de 1879. Avultava especialmente a capacidade de mobilização popular, uma vertente tendencialmente distante das práticas partidárias dos partidos afectos ao constitucionalismo monárquico.

Entre as leituras subordinadas ao Tricentenário, não escassearam as análises à conduta de D. Luís. Decerto a resolução em participar na efeméride ao Bardo não diluíam a negatividade subjacente ao carácter extemporâneo da decisão nem o distanciamento físico mantido entre a figura régia e demais participantes, por vontade expressa do rei. Estas apreciações ecoavam na imprensa, não exclusivamente republicana como se extraia do editorial do poeta e jornalista Guilherme de Azevedo ${ }^{54}$ em O Ocidente. Revista lustrada de Portugal e do Estrangeiro. A escolha régia em manter-se voluntariamente à margem do cortejo cívico inspirava as reflexões de Azevedo sobre a centralidade do povo na vida politica portuguesa.

"E o grande cortejo cívico permanecerá por longos anos na memória popular. Via-se, pela primeira vez nos tempos modernos, uma grande procissão, um comprimento descomunal, sair do Terreiro do Paço à hora prefixa - e todavia, não levava as basílicas da sé, não levava capelães cantores, não marchava entre alas de soldados; era uma procissão em que o ídolo era o povo glorificado pelo próprio povo, recebendo pela primeira vez a sua apoteose e adquirindo a noção pacífica a que muitos chamam reaccionária, de que ele é rei, e de que, em vez de marchar com uma cana verde na mão pode, quando tenha consciência do seu direito e da sua força, marchar antes com um ceptro"55.

$\mathrm{Na}$ perspectiva de Azevedo, as festas do Centenário avultavam a um dos factos "mais profundamente revolucionários que em Portugal se tem realizado"56. Tal caracterização residia na natureza da estrutura organizativa do Tricentenário, inteiramente alheada do Estado, antes radicada na afirmação efectiva da sociedade portuguesa. Nas suas palavras, "as festas do Centenário, ainda que não tivessem outras vantagens e representassem outras afirmações, afirmaram pelo menos o seguinte: a inutilidade dos poderes constituídos em face da iniciativa privada"57. Tratava-se de uma demonstração colectiva de competência na concepção e na execução exemplar do plano definido. Consistia, por outro lado, numa realização capaz de concitar as atenções e merecimentos das potências europeias. Nem os boatos de insurreição sanguinária, nem os cenários de atentado das forças radicais contra o Rei encontraram correspondência com a realidade. Nas festas do Centenário, só a Monarquia Constitucional parecia destoar pelo emprego de força militar excessiva usada autoridades. Ou ainda o zelo na apreciação dos cartazes das corporações de trabalhadores, o que justificaria a apreensão de uma bandeira com o seguinte mote "Não mais deveres, sem direitos. Não mais direitos, sem deveres"58.

\footnotetext{
${ }^{54}$ Guilherme de Azevedo, Crónica Ocidental, coord. por Ernesto Rodrigues, Lisboa, Espera do Caos, 2016.

${ }^{55}$ Guilherme de Azevedo, "Crónica Ocidental”. O Ocidente. Revista Ilustrada de Portugal e do Estrangeiro, $\mathrm{n}^{\circ}$ 60, 15 de Junho de 1880, p. 102.

${ }^{56}$ Guilherme de Azevedo, “Crónica Ocidental”. O Ocidente, op. cit., p. 102.

${ }^{57}$ Guilherme de Azevedo, “Crónica Ocidental”. O Ocidente, op. cit., p. 102.

${ }^{58}$ Guilherme de Azevedo, “Crónica Ocidental”. O Ocidente, op. cit., p. 102.
} 
Nos periódicos republicanos, o elogio ao povo e a crítica velada a D. Luís cedia espaço a apreciações contundentes sobre o carácter pernicioso das estruturas institucionais da monarquia constitucional e respectivos agentes. Neste articulado, o comemorativismo camoniano de Junho de 1880 assumia os contornos paradigmáticos das vivências politicas coevas, clarificando as relações entre elites e povo, entre o chefe de estado e o governo ou, não menos importante entre o monarca e o povo. O Almanach do Trinta para 1881 dedicava parcialmente o "Juizo do Ano" ao significado e à leitura pedagógica do Tricentenário, retratado como um momento de emancipação popular ${ }^{59}$. Escalpelizando os procedimentos de cada interveniente, o rei, o governo e o povo, o periódico dirigido pelo republicano Cecílio de Sousa (1842-1897) antecipava o ano vindouro - "O mundo português será regido pelo sistema chamado liberal, no mesmo, se não pior pé, de torpeza e misérias"60 - embora enfatizasse o surgimento de novos elementos actuantes na conjuntura política:

"O rei separado, pelo seu governo, do povo que ainda acreditava na tradição da monarquia virá, ele próprio mostrar ao povo a inutilidade da sua existência, o desnecessário do seu poder real, visto que o povo, abstraindo do rei, pode manifestar-se, definir-se, afirmar-se, categoricamente, sem a sua presença ou auxílio. Foi isto que o povo já fez no Tricentenário de Camões. Foi o começo"61.

Tratava-se efectivamente do início de um processo; no entanto, esta dinâmica resultava igualmente do próprio rei $\mathrm{D}$. Luís, fosse por acatar as recomendações do executivo, fosse pelo modo como justificava a conduta com base das orientações governativas: "o rei, desculpando-se da sua ausência do cortejo com as imposições do seu ministério, atirou com o pobre diabo às vaias do país e foi para casa contar a partida aos seus áulicos da camarilha real. E ao jantar, todos se riram do pobre governo"62.

As dimensões tutelar e equidistante, quais prerrogativas régias para zelo constante da harmonia entre poderes, transmutavam-se em distanciamento, frieza e insensibilidade em face da disputa partidária cuja agressividade e corrupção de práticas eram justamente estimuladas pelo chefe de estado. " $E$ agora ri-se ainda, o bom rei, ao ver como o mastim rosna na esburgadela do seu osso, virando o dente agudo aos outros mastins que estão sentados à roda, graves, pacientes, atentos ao mais ligeiro descuido do mastim que ainda roe"63.

Nesta conformidade, o rescaldo do Tricentenário Camomiano propiciava o regresso do debate interno sobre a Monarquia Constitucional e, particularmente, acerca das funções reservadas ao rei neste âmbito institucional. Em Outubro de 1880, a modernização do abastecimento de água a Lisboa dava o mote para as reflexões tecidas por Gervásio Lobato (1850-1895), cronista e escritor, acerca do sistema politico nacional em face das lógicas de representação intrínsecas à natureza do estado português.

\footnotetext{
59 “Juízo do Ano", Almanach do Trinta para 1881, II Ano, Lisboa, Tipografia Popular, 1880, p. 52.

60 “Juízo do Ano”, Almanach do Trinta para 1881, op. cit., p. 52.

61 "Juízo do Ano", Almanach do Trinta para 1881, op. cit., , p. 52.

62 “Juízo do Ano", Almanach do Trinta para 1881, op. cit., p. 53.

63 “ Juízo do Ano”, Almanach do Trinta para 1881, op. cit., p. 53.
} 
Fazendo amplo recurso à sátira, o autor, a quem não se conheciam convicções politicas anti-monárquicas, espraiava-se na descrição da cerimónia inaugural da Estação Elevatória a Vapor dos Barbadinhos, ora considerada como paradigmática da realidade institucional portuguesa e, simultaneamente, reveladora dos valores e práticas do constitucionalismo. Na recepção ao rio Alviela em Lisboa marcavam presença as principais figuras do Estado, o rei e o executivo, mas também a estrutura eclesiástica, representada pelo arcebispo de Mitilene e "sua corte sacra", dignitários oriundos de potências aliadas, o Principe de Gales, então de visita a Portugal, um contexto protocolar não isento de gafes nem de litigâncias multisseculares - revelada na recusa afrontosa do arcebispo em cumprimentar o convidado estrangeiro, de confissão religiosa protestante. Observe-se porém a ênfase concedida pelo cronista ao posicionamento reservado à Família Real, corroborado pelo trato exclusivo, no decurso da recepção.

"Na cabeça do pavilhão estava a mesa real, servindo também de cabeça, no grande bufete arrumado no resto da barraca. A mesa real era mais elevada, tanto carpinteiramente como gastronomicamente falando. Assim devia forçosamente ser dentro do organismo constitucional. Na mesa real comia-se sentado e na outra em pé; naquele devorava-se pavão, neste perú. Aqui tem a diferença que nos países monárquicos medeia entre a cabeça e o corpo social, a diferença que medeia entre o pavão e o perú"64.

A denominada "Festa do Alviela" era igualmente acolhida no "Juízo do Ano", no Almanach do Trinta para 1881. Neste periódico, as atenções concentravam-se na caracterização genérica da elite portuguesa - "Tanta gente de casaca/ Parece enterro graúdo!/ Dança de velhos de entrudo/ Creio bem que não será/ Muitos vêm d'americano/ Por ser viagem barata/ Uns vêm de trem, outros à pata/ Em bica suando já"65 - retratada com sarcasmo. Porém, o interesse do Almanach centrava-se especialmente na proximidade entre rei e arcebispo, enfatizando a prevalência da aliança entre o trono e o altar - "Levantou el-Rei a adufa/ E a água correu em barda/ Ninguém se lembrou da albarda/ Ninguém sentiu o selim/ O reverendo arcebispo/ De grande hyssope na unha/ Disse em tom de caramunha/ Quatro asneiras em latim"66.

Esta convergência, de efeitos perniciosos para a promoção das liberdades individuais do cidadão, alcançava consequência ainda mais gravosas por legitimar a manutenção da componente clerical entendida como parasitária da sociedade portuguesa - "Qual bando de gafanhotos/ Danados com a fome tesa"67.

No mesmo passo, o desempenho de D. Luís, reconhecido como patrono das Artes, melómano, literato e tradutor das obras de William Shakespeare ${ }^{68}$, parecia

\footnotetext{
${ }^{64}$ Gervásio Lobato, Crónica Ocidental, O Ocidente. Revista Ilustrada de Portugal e do Estrangeiro, $\mathrm{n}^{\circ} 68,15$ de Outubro de 1880, p. 166.

65 “Juízo do Ano”, Almanach do Trinta para 1881, II Ano, Lisboa, Tipografia Popular, 1880, p. 141.

66 "Juízo do Ano", Almanach do Trinta para 1881, op. cit., p. 141.

67 “Juízo do Ano", Almanach do Trinta para 1881, op. cit., p. 141.

${ }^{68}$ Hamlet: drama em cinco actos. Tradução portuguesa de D.Luís I, Lisboa, Imprensa Nacional, 1877, $2^{\mathrm{a}}$ ed. em 1880; Mercador de Veneza. Drama em cinco actos. Tradução de D.Luís, Lisboa, Imprensa Nacional, 1879 ; Ricardo III. Drama histórico em cinco acto. Tradução de D.Luís I, Lisboa, Imprensa Nacional, 1880; Othelo, o mouro de Veneza de William Shakespeare: tragédia em cinco actos traduzida para português por D.Luís de Bragança, Lisboa, Imprensa Nacional, 1885.
} 
não impressionar este periódico que, a propósito do Congresso de Antropológico e Literário realizado em Lisboa, no mesmo mês, parodiava os pruridos evidenciados na imprensa monárquica na divulgação da cerimónia de abertura do evento:

"O Rei de Portugal presidiu, dizem uns, na qualidade de tradutor de Hamlet; outros dizem que foi o tradutor de Hamlet que presidiu na qualidade de rei de Portugal. Sobre isto suscitou-se a questão que tem de ser decidida no futuro congresso em Viena d'Áustria, devendo ser por isso o principal objecto das meditações dos antropólogos durante o futuro ano"69.

A capacidade régia de apreender os novos fenómenos sociais em curso, mormente os incidentes nas grandes áreas urbanas, não era objecto de menção do Almanach. Porém, surgia enfatizada nas páginas de $O$ Ocidente, atento a disponibilidade de D. Luís em inovar as práticas assistenciais atendendo à expansão demográfica exponencial de Lisboa e Porto e à emergência de novos focos de pobreza citadina. A inauguração dos Albergues Nocturnos, a 18 de Outubro de 1881, suscitava os maiores encómios de Lobato a D. Luís, enquanto promotor da "iniciativa civilizada e caridosa"70; tratava-se do "primeiro olhar dos poderes públicos para a miséria que se arrasta pelas ruas. Veio de alto esse olhar e oxalá sirva de exemplo"71.

Igualmente exemplar, aos olhos de Gervásio Lobato, de resto inexplicável, avultava o interesse do lisboeta nos actos cerimoniais associados à actividade das câmaras legislativas, em particular nos actos de abertura e encerramento bem como as discussões parlamentares. Observe-se ainda que tal não fosse secundado com entusiasmo nos sufrágios eleitorais. Na perspectiva de Lobato, tratava-se de um "espectáculo pobrezinho, sem grande aparato, nem guardaroupa"; porém, a "empresa-nação" proporcionava um grande atractivo, inigualável por qualquer casa de espectáculos do país: concedia "divertimentos gratuitos"72.

Assim, a monarquia constitucional parecia mobilizar a cidade de Lisboa a cada dia 2 de Janeiro: "almoça cedo e põe-se a caminho de S. Bento". Decerto, nem todos os interessados poderiam aceder às instalações das Cortes Gerais, no entanto, "cada cidadão tem na sua algibeira dez ou doze bilhetes para esse espectáculo. O governo, na impossibilidade material de dar a todos os portugueses de aquém e dalém mar um lugar nas galerias de S. Bento, tem a bizarria de lhes dar em compensação um bilhete".

Ao apreço do lisboeta pela dimensão de espectacularidade cénica e protocolar da abertura das Cortes Gerais, amplamente estimulada pelo executivo através da prática de atribuição de ingresso em S. Bento, acrescia um fenómeno caracterizado como bizarria idiossincrática da vivência nacional - as apostas. $O$ lisboeta, "muito grave, muito sisudo", familiarizou-se com o hipódromo onde apreciava os cavalos sem despender um real. Contudo, o espectro de crise politica

\footnotetext{
69 “Juízo do Ano”, Almanach do Trinta para 1881, op. cit., p. 159.

${ }^{70}$ Gervásio Lobato, “Crónica Ocidental”, O Ocidente. Revista Ilustrada de Portugal e do Estrangeiro, n ${ }^{\circ} 105,21$ de Novembro de 1881, p 257.

${ }^{71}$ Gervásio Lobato, “Crónica Ocidental”, O Ocidente, op. cit., p 257.

${ }^{72}$ Gervásio Lobato, "Crónica Ocidental”, O Ocidente. Revista Ilustrada de Portugal e do Estrangeiros, $\mathrm{n}^{\mathrm{0}} 74,11$ de Janeiro de 1881, p. 8.
} 
e partidária acalentava acerrimamente os espíritos da capital; o cunho dramático impresso ao discurso político, produzidos pelo governo ou formulados pela oposição, acerca da concessão de nova fornada de Pares do Reino, do encerramento das câmaras ou qualquer ou assunto de Estado despertava no lisboeta uma reacção paradoxal: "pega na bolsa e aposta. Se há fornada, cinco tostões; se não há fornada, abala-se a monarquia, setecentos e vinte. E Portugal, que nas corridas de cavalos se mantém anhelante, recolhido e grave, quando vê que a coroa está em risco, não lhe quer ficar atrás e arrisca a sua meia coroa"73.

\section{S.P.Q.R. - SENHOR, O POVO QUER REPÚBLICA}

Em Lisboa, o entendimento da política enquanto actividade recreativa, cujo carácter lúdico tornava a administração da coisa pública comparável ao apreço pelos teatros e posteriormente pelos animatógrafos, possibilitava antever mutações substanciais em curso nos padrões comportamentais e na estrutura mental da população do lisboeta. A Semana Santa de 1881 inscrevia-se neste fenómeno e legava um testemunho inequivoco da mudança: longe das vivências religiosas, originalmente elementos essenciais e exclusivos da quadra, a Páscoa adquiria novos sentidos, tendencialmente desprovidos de religiosidade. Sem desprimor, a tradição mantinha-se e as procissões realizaram-se embora "sem espectadores nem actores". Ou, pelo menos, sem os habituais fiéis outrora: em 1881, as festividades da quadra revelavam-se um cenário reconfigurado de interacção dos domínios político e religioso. Se antes obedecia exclusivamente à esfera monárquica, tributária da existência de religião oficial do estado, no início da década de 80, esta correlação espraiava-se a outras correntes políticas, mormente o republicanismo. Na procissão do Domingo de Ramos, D. Luís era confrontado com o pedido de mudança de regime, materializado nos pendões de algumas confrarias da capital.

Tendencialmente laica e predisposta à viragem institucional, amiúde Lisboa mostrava ser um cenário de intranquilidade social endémica, não raras vezes acompanhado pelo espectro da revolução. Com frequência, os boatos irrompiam para agitação dos "espíritos e dos cavalos da Guarda Municipal", fórmula suavizada para definir as dificuldades crescentes das autoridades em controlar a capital entregue ao debate politico e seduzida pelos meetings, uma moda "antihigiénica" que, após perpassar pelo espaço público e mobilizar as grandes praças lisboetas, ficava restringida ao perimetro particular, por força da intervenção das autoridades $^{74}$. Porém o movimento subsistia e, nos anos subsequentes, a imagem da hidra revolucionária emergia esporadicamente nos meios urbanos, especialmente na capital.

O mês de Janeiro de 1882 revelava-se paradigmático do fenómeno supramencionado: Lisboa fervilhava com uma onda de boatos sobre a actividade dos meandros conspirativos e a eclosão revolucionária. $\mathrm{Na}$ esteira dos procedimentos adoptados no passado próximo, a monarquia constitucional, por seu turno, reagia, através das entidades administrativas e policiais, com

\footnotetext{
73 Gervásio Lobato, “Crónica Ocidental”, O Ocidente. Revista Ilustrada de Portugal e do Estrangeiro, n 74,11 de Janeiro de 1881, p. 10.

${ }^{74}$ O Ocidente. Revista Ilustrada de Portugal e do Estrangeiro, $\mathrm{n}^{\mathrm{o}}$ 80, 11 de Março de 1881, p. 58.
} 
vigilância reforçada sobre publicações, periódicos e actividades teatrais. Estas medidas, de carácter transversal, visavam especialmente os autores e os títulos republicanos, os quais retorquiam com um discurso de agressividade redobrada contra as instituições monárquicas e a interpretação restrita do direito de liberdade de imprensa.

Neste ambiente de conflituosidade politica e social, Lisboa recebia a visita oficial dos Reis de Espanha, acompanhados pelo presidente do governo, Práxedes Mateo Sagasta. A vinda de Alfonso XII a Portugal devia-se ao acolhimento favorável dado convite de $D$. Luís para a festa artística e industrial de inauguração da Exposição de Arte Ornamental e Decorativa da Península Ibérica. A estada dos Reis de Espanha decorreu entre os dias 10 e 17 de Janeiro e caracterizou-se por um conjunto de cerimónias oficiais e actividades de índole privada, repartidas entre Lisboa, Sintra e Vila Viçosa.

A presença dos monarcas espanhóis em Portugal, num período de contestação crescente às estruturas institucionais portuguesas e, particularmente, ao rei, propiciava um exercício de reflexão sobre as monarquias europeias oitocentistas, o papel dessa instituição política e as dinâmicas evolutivas assumidas pela mesma perante as mutações estruturais de natureza económica e social, ocasionadas pelo advento da contemporaneidade. Observe-se, neste contexto, o editorial d' O Ocidente: "A realeza é hoje um dos encargos mais pesados que pode assumir um homem e sobretudo uma mulher. As abdicações que denunciavam outrora a abnegação do filósofo, hoje representam simplesmente o egoísmo de um comodista"75.

Segundo esta perspectiva, as instituições monárquicas confrontavam-se com a necessidade de se reinventarem à luz do principio de separação de poderes. Porém, o século XIX representava novos desafios para a coesão e para a integridade dos estados soberanos, uma vertente na qual os reis constitucionais desempenhavam uma função primordial assente na manutenção dos valores identitários da comunidade. A prossecução dessa tarefa impunha uma redefinição do posicionamento da figura régia na vida pública uma vez que, "nesta luta medonha que se trava em toda a parte, entre a sociedade e a revolução, os reis combatem na vanguarda"76. De resto, o publicista enfatizava um dos aspectos mais paradoxais da centralidade renovada dos reis que, "quanto mais invioláveis os fazem as constituições, mais apetece atirar-lhes. Perante as câmaras, os ministros são responsáveis pelos actos do Reis mas perante o revólver, os reis são responsáveis pelos actos dos ministros"77.

As impressões genéricas observavam uma função preambular à análise da personalidade e acção políticas de D. Alfonso XII. Partindo de uma premissa basilar, a dificuldade da Europa continental - povos e mesmos reis - em compreender e agir segundo os parâmetros da fórmula monárquica constitucional, importada da Inglaterra, o articulista sublinhava o rei de Espanha: "D. Afonso XII é um dos homens que tem sabido admiravelmente

\footnotetext{
${ }^{75}$ O Ocidente, Revista Ilustrada de Portugal e do Estrangeiro, $\mathrm{n}^{\mathrm{o}}$ 110, 11 de Janeiro de 1882, p. 10.

${ }^{76}$ O Ocidente, op. cit., p. 10.

${ }^{77}$ O Ocidente, op. cit., p. 10.
} 
percebê-la"78. Para essa lucidez e capacidade de actuação contribuía activamente, segundo o autor, a educação recebida no exílio e a forma fraternal como o rei, enquanto jovem, privara fraternalmente com republicanos e monárquicos.

O perfil traçado sobre o monarca espanhol, em face da completa ausência de referências ao rei anfitrião, constituía uma crítica subliminar a D. Luís. Esta fórmula distinguia-se das considerações explícitas reservadas à elite política portuguesa, quando comparada com a prestação de Sagasta em Lisboa: “entre o grande estadista de Espanha e os estadistas pequeninos da nossa terra, há uma diferença enorme, felizmente para a Espanha"79.

Entre os sectores republicanos radicais portugueses, a figura de D. Alfonso XII merecia apreciações absolutamente inversas e, nessa medida, nada continha que pudesse ser apresentado como modelar para a coroa portuguesa. $O$ Fuzilamento de Numancia concitava os ânimos enfurecidos contra o monarca espanhol o qual dava mostras inequívocas de ser um Bourbon: "Os Bourbons de Espanha deram-se mais uma vez ao seu prazer sensual, de cevar o ódio que nutrem pela liberdade no sangue de quatro filhos do povo"80. A conduta de D. Alfonso XII era justificada pela ascendência familiar; ao decretar o fuzilamento dos insurgentes, o rei de Espanha não fazia mais do que agir em conformidade com o biologismo hereditário, uma das características marcantes e funestas associadas aos regimes monárquicos: "Mas o coração dos Bourbons, raça maldita que os vícios corroem e a morte vai extinguindo, não possui nenhum dos impulsos generosos que são a honra da humanidade"81. Sem pruridos, o Almanach do Trinta formulava o desejo de uma mudança de regime em Espanha, definida como "a nossa irmã mais velha e mais querida" ${ }^{2}$; assente na convicção de que a queda dos Bourbons significava a inexorável derrocada dos Braganças em Portugal.

Em 1883, o republicanismo radical não constituía a única fonte de apreensão para a imagem pública da Monarquia Constitucional e do rei. A queda do executivo progressista reavivava as críticas desse partido ao poder moderador e, a breve trecho, a imprensa afecta à estrutura partidária promovia uma campanha acérrima contra D. Luís, uma vez mais acusado de favorecer o Partido Regenerador, também denominado por "partido do rei". Segundo a perspectiva progressista, D. Luís incumpria de forma reiterada os cânones consagrados pela Carta Constitucional e lesava o princípio de equidistância sob a égide do qual o rei reina, não governa. A solução sugerida pelos progressistas configurava a abdicação régia em favor do príncipe D. Carlos, uma fórmula abundantemente publicitada por Emídio Navarro e Mariano de Carvalho ${ }^{83}$.

A fórmula reinante desejável aos Progressistas desagradava a D. Luís e à Casa Real Portuguesa. Por precaução, o príncipe era deslocado da corte e

\footnotetext{
${ }^{78}$ O Ocidente, op. cit., p. 10.

${ }^{79}$ O Ocidente, op. cit., p. 18.

80 “Os Fuzilados”, Almanach do Trinta para 1884, V Ano, Lisboa, Tipografia Popular, 1882, p. 84.

81 “Os Fuzilados”, Almanach do Trinta para 1884, op. cit., p. 85.

82 “A Revolução de Espanha e os Quatro Fuzilados de Numancia”, Almanach do Trinta para 1884, V Ano, Lisboa, Tipografia Popular, 1882, p 22.

${ }^{83}$ Eduardo Schwalbach, À Lareira do Passado, Lisboa, Ed. do Autor, 1944.
} 
colocado em serviço regular em Cavalaria 1, de Elvas. Com o afastamento físico de Lisboa, o rei pretendia salvaguardar a imagem do Príncipe e torná-lo impermeável à campanha progressista de substituição do chefe de estado. A estada em Elvas não lograva os efeitos desejados e, em Setembro de 1884, o nome do príncipe figurava no elenco de militares conspiradores que, conforme os boatos, intentavam um golpe de estado contra D. Luís. Segundo o inquérito subsequente, as movimentações da unidade militar obedeciam exclusivamente a indisciplina, fundamento para a sua posterior dissolução, decretado pelo chefe do executivo, Fontes Pereira de Melo. O principe D. Carlos, por seu turno, recolhia ao Paço Ducal de Vila Viçosa, uma permanência oficialmente justificada por motivos de saúde.

Para os republicanos portugueses, a figura do filho primogénito do casal real não era indiferente. Pelo contrário, mostravam-se atentos às características pessoais, aos primores aplicados na formação do futuro rei e ao desempenho do sucessor do trono. Assim observe-se que, enquanto os Progressistas seduziam o principe a assumir as responsabilidades institucionais do pai, os republicanos traçavam um retrato particularmente satírico do futuro monarca português. Recorrendo à forma poética, o Almanach do Trinta usava o humor para desacreditar o herdeiro da Casa Real: "O Simãosinho louro, um bom petiz galante/ Que agora anda correndo as três partes do mundo/ Tem feito estudos tais no curso de reinante/ Que nos enche de pasmo e de assombro profundo"84. O cosmopolitismo do príncipe enfatizado - "Ele foi a Berlim, à China e à Dinamarca" - inscrevia-se num tema recorrente e popular, da propaganda republicana, o despesismo da Casa Real.

Por outro lado, as finanças públicas e a diplomacia comercial, prioritárias para os executivos da época surgia representado - "Ele discute o cebo e rolhas e orçamentos/ Ele conhece até os quatro ventos/ E saiu-nos enfim, um chichisbeu de marca"85. Emblemático do esforço de adequação da Monarquia Constitucional portuguesa às contingências da contemporaneidade - "Já não é como outrora em dias sensabores/ na frase consagrada, um dos reais penhores/ Bijou de biscuit e pêssego sem pelo", afinal o herdeiro da Casa Real não podia simbolizar senão a continuidade dos aspectos mais condenáveis do regime monárquico: “Agora é melro fino, afirmam as gazetas / Conquista a cada hora oitenta Julietas / O louro simãosinho é d'alto lá com ele"86.

Em 28 de Dezembro de 1889, o principe transformava-se em rei de Portugal: então com 26 anos, era simultaneamente o novo monarca de Portugal e o mais jovem em funções na Europa da época. D. Carlos era conhecido pela proximidade ao grupo Vencidos da Vida, assim denominado o conjunto de intelectuais portugueses empenhados na reestruturação das instituições monárquicas, atendendo à incapacidade de renovação institucional no quadro do regime instituído. Motivados pela consciência de crise nacional, caracterizada como a desagregação do edificio político, fruto do desajustamento entre os ideais do liberalismo e o processo de implementação, estes intelectuais preconizavam um

\footnotetext{
84 “O Simãosinho Real”, Almanach do Trinta para 1884, V Ano, Lisboa, Tipografia Popular, 1882, p 102.

85 O Simãosinho Real”, Almanach do Trinta para 1884, op. cit., p 102.

${ }^{86}$ O Simãosinho Real”, Almanach do Trinta para 1884, op. cit., p 102
} 
entendimento revolucionário dos poderes do rei, forma de resgatar o regime monárquico e evitar a eclosão revolucionária republicana.

Neste núcleo de intelectuais avultavam Ramalho Ortigão, Oliveira Martins, Eça de Queiroz e Guerra Junqueiro, ou políticos destacados como António de Serpa Pimentel e o conde Casal Ribeiro entretanto acompanhados de outros elementos como Carlos Lobo de Ávila, Bernardo Pinheiro Correia de Melo e o conde de Sabugosa, entusiastas do projecto da Geração de 70. Este último seria o obreiro do vínculo estabelecido entre o herdeiro da Coroa e esta elite, cujo ideário se repercutia na assunção de um protagonismo renovado da figura real no quadro político e público nacional.

Em 11 de Janeiro de 1890, Portugal era intimado a proceder à retirada da coluna liderada por Serpa Pinto, em expedição às terras do Chire, sob pena de ruptura e conflito armado com a Inglaterra. A resposta do governo português ao Ultimatum britânico não tardou e inscreveu-se no sentido das pretensões britânicas. O cenário de conflito bélico com a Inglaterra era afastado; porém, em Portugal emergia uma ampla onda de indignação acérrima contra os agentes externo e interno do desaire nacional. Na propaganda republicana, a prepotência inglesa e a monarquia constitucional portuguesa eram retratadas no mesmo passo, uma mensagem que obteve elevada adesão da população lisboeta. A capital submergia numa espiral de violência crescente à qual nem $\mathrm{D}$. Carlos I escapava, apresentado como um dos responsáveis pelo prejuízo nacional, opinião parcialmente veiculada também pelo Partido Progressista.

As negociações com a Inglaterra para definição fronteiriça de Angola e Moçambique arrastaram-se até 11 de Junho de 1891, com perdas territoriais e de direitos para Portugal, compensadas pela inclusão de novos espaços no domínio nacional. Encerrava-se o litígio com a Inglaterra, mas não sem consequências internas para a monarquia constitucional confrontada, em 31 de Janeiro de 1891, pela insurreição republicana do Porto. Este movimento era motivado por uma confluência de factores políticos e ideológicos, a saber, a aspiração à mudança em conformidade com o ideário do Partido Republicano, mas também de natureza corporativa, como a transferência de sargentos e o índice salarial. Fortemente reprimido pelas tropas fiéis ao regime, as repercussões deste episódio ecoaram dentro e fora das fronteiras nacionais: mais do que um aviso às instituições monárquicas, a insurreição republicana portuense era demonstrativa da fragilidade da coroa portuguesa, imagem propalada entre as potências europeias, especialmente em Inglaterra, no decurso do processo negocial decorrido no Outono de 1890. Em carta à rainha Vitória, o rei português atestava a gravidade da situação vivida em Portugal, uma visão amplamente difundida na imprensa liberal inglesa, convicta das responsabilidades do governo do Lord Salisbury na eventual na derrocada do regime monárquico português e mesmo na hipotética eclosão de um movimento republicano em toda a Península Ibérica. Esta hipótese constituía motivo de preocupação para as casas reinantes da Europa, atendendo à situação geográfica peninsular perante a França republicana. Em última análise, a possibilidade de uma república ibérica fortalecia a França, para desagrado do Império Alemão que, nessa medida, intentou um esboço de aproximação à Rússia.

Súbita e estranhamente, a monarquia constitucional portuguesa era catapultada como garante do equilíbrio de forças na Europa, uma perspectiva 
não compartilhada pelo Lord Salisbury. Pelo contrário, "se a monarquia portuguesa está tão desesperadamente fraca que as nossas exigências a podem destruir, então não vale a pena salvá-la”. Em Portugal, o impacto desta leitura sobre os assuntos politicos portugueses fragilizava a figura régia e comprometia o futuro das instituições monárquicas. Na Europa adivinhava-se para breve o fim da monarquia portuguesa.

\section{DO ENGRANDECIMENTO DO PODER REAL AO OCASO DA MONARQUIA CONSTITUCIONAL PORTUGUESA: O REI E O ESPAÇO PÚBLICO}

No rescaldo da insurreição republicana, ocorrida em Janeiro de 1891, eclodia a crise financeira do Estado Português, com impacto relevante na vida pública nacional nos dois anos subsequentes. Nessa medida, os factores de precaridade, endógena e exógena, da monarquia constitucional portuguesa avolumavam-se inexoravelmente. Porém, a Família Real esforçava-se por regressar à normalidade. Para tal, desenvolviam um périplo pela Beira Baixa - Castelo Branco e Covilhã -, a pretexto da inauguração da via-férrea, entre os dias 5 e 8 de Setembro de 1891; posteriormente uma deslocação ao norte onde permaneceu de 18 de Novembro a 1 de Dezembro do mesmo ano. Tratava-se do cumprimento de uma rotina habitual aquando da aclamação de um novo rei, cumprido o período de nojo por morte do antecessor régio. Neste caso, a saudação à segunda cidade do país tardava em realizar-se devido às pressões politicas surgidas com o Ultimato britânico e principalmente com a insurreição republicana no Porto. Estes dois factores convergiam no adiamento da ida da Família Real ao Porto para prestar homenagem à cidade fundadora da monarquia constitucional ${ }^{87}$.

Dez meses após revolta republicana, a deslocação ao norte era imperativa na agenda régia para o reforço da ligação entre o Chefe de Estado e as populações nortenhas, além da apresentação do herdeiro da coroa. Ambos os dois objectivos seriam amplamente conseguidos. Mais, na permanência no Porto e nas visitas a Braga, Guimarães, Viana do Castelo e Leixões, o Rei foi recebido com o manifesto agrado e ampla afectividade populares em manifestações diversas. A viagem ao norte conferia a D. Carlos maior solidez e segurança no desempenho das atribuições régias. Porém, não menos relevante, esta deslocação ao norte estabelecia as premissas basilares da geografia política nacional, prevalecente até Outubro de 1910, a saber a adesão do litoral norte à monarquia constitucional por oposição a Lisboa e à região do Vale do Tejo, afectas ao republicanismo, de índole revolucionária, no caso da capital.

A primeira visita oficial externa de D. Carlos correspondia às necessidades da diplomacia portuguesa, no rescaldo do Ultimato britânico, a um reforço de relações com o vizinho ibérico. Tratava-se de uma aproximação política, corroborada pela valência económico, como se depreendia do Tratado de Comércio com a Espanha, assinado em 1893. Realizada entre os dias 9 e 18 de Novembro de 1892, esta viagem oficial pretendia suscitar um novo modus vivendi com o regime de Afonso XIII, assente na circunstância da partilha do mesmo espaço geográfico na Europa, como da condição similar enquanto potências

\footnotetext{
${ }^{87}$ Teresa Nunes, D.Carlos. O Diplomata 1889-1908, Matosinhos, Academia Portuguesa de História/QuidNovi,
} 2009, pp. 32-37. 
coloniais contestadas. Bem-sucedida, esta passagem de D. Carlos por Madrid contribuiu para lançar uma imagem de prestígio do jovem rei na Europa. Permitiria estabelecer um diálogo privilegiado com Afonso XIII, patente na homenagem correspondente prestada pelo rei espanhol a Portugal, em 10 de Dezembro de 1903 e na aproximação diplomática dos dois países no quadro das alianças estabelecidas no período anterior à Grande Guerra ${ }^{88}$.

Em 1895, D. Carlos I retomava as viagens ao exterior: entre 2 de Outubro de 16 de Novembro, fazia um périplo por França, Inglaterra e Alemanha. Antes, em 3 de Maio, a chegada do representante do Brasil em Portugal marcava o restabelecimento de relações diplomáticas entre os dois países. Em Setembro de 1897, o rei do Sião era recebido em Cascais. Posteriormente, em Janeiro de 1901, a morte da rainha levava D. Carlos a Inglaterra onde regressava, no ano seguintes, para assistir à coroação de Eduardo VII. O gesto retribuído pelo monarca inglês em Abril de 1903, com uma visita oficial a Lisboa. No mesmo ano, D. Afonso XIII rumava a Portugal: seria recebido na capital e em Vila Viçosa. Em 1904, o Casal Real deslocou-se a Inglaterra, país onde permanecia entre 12 de Novembro e 20 de Dezembro (a qual foi assinado um tratado de arbitragem entre as duas potências em Windsor).

O ano subsequente registou elevada actividade diplomática: o irmão de Eduardo VII vinha a Lisboa, entre 7 e 12 de Janeiro; dois meses após chegavam a rainha Alexandra e as princesas Vitória e Maud, do Reino Unido, acompanhadas pelo príncipe Carlos da Dinamarca, casado com a última. Entre os dias 27 e 30 de Março, a capital portuguesa recebia o imperador Guilherme II da Alemanha, o qual gerava grande expectativa em Lisboa ou não fosse o imperador a "imagem simbólica dessa Alemanha beliciosa" 89 . Afinal, Guilherme II era apenas um jovem "com suas as faces rosadas, o seu cabelo louro, os seus braços assimétricos, o seu aspecto quase tímido de juvenil coronel de cavalaria 4"90. Afirmações semelhantes eram inspiradas por D. Afonso XIII aquando da sua estada em Portugal. Ainda em 1905, Portugal recebia a visita do presidente francês, Émile Loubet, entre os dias 27 e 29 de Outubro, retribuída pelo chefe de Estado português, no final do mês de Novembro, e prolongada por um mês até 20 de Dezembro.

Em 1907, a actividade diplomática da Casa Real portuguesa mantinha-se: Lisboa recebia Frederico Augusto III, rei do Saxe, neto de D. Maria II, em 7 de Março. Sucedia a deslocação particular da rainha, com os infantes, a Sevilha, para a Semana Santa. Em 1 de Julho, iniciava-se uma longa digressão do príncipe herdeiro Luís Filipe, pelo império, finda em 27 de Setembro. Antes do final do ano, D. Amélia rumava a Inglaterra para participar no casamento da irmã, Louise, circunstância onde privava com parte da realeza europeia, em particular, Eduardo VII, Guilherme II e Afonso XIII. Regressava a Portugal em 6 de Dezembro, depois de uma breve passagem por França ${ }^{91}$.

\footnotetext{
${ }^{88}$ Teresa Nunes, D. Carlos. O Diplomata, op. cit., pp. 38-41.

${ }^{89}$ Teresa Nunes, D. Carlos. O Diplomata, op. cit., p. 40.

${ }^{90}$ Teresa Nunes, D. Carlos. O Diplomata, op. cit., p. 40

${ }^{91}$ Teresa Nunes, D. Carlos. O Diplomata, op. cit., pp. 42-46.
} 
Esta popularidade, cultivada no plano externo, não encontrava paralelo em Portugal; internamente, e D. Carlos congregou contestação crescente das diversas forças partidárias monárquicas, das quais dependia, em última análise, a estabilidade governativa. Esta, por seu turno, alicerçava-se na composição da câmara dos deputados, pelo que não raras vezes, perante a queda do executivo em funções, a opção régia na indigitação de um novo governo impunha a dissolução das câmaras e o agendamento de um novo sufrágio eleitoral numa perspectiva cronológica próxima. Este procedimento de excepcionalidade previsto nos termos consagrados na Carta Constitucional para o funcionamento do poder legislativo, não sendo inaugurado no reinado de D. Carlos, tendia à vulgarização durante os dezanove anos subsequentes ao juramento do rei em Dezembro de 1889.

Em Maio de 1906, D. Carlos quebrava objectivamente a prática tornada rotineira desde 1893, um dos esteios da sobrevivência do rotativismo. Preparavase para instaurar uma nova ordem e um novo ciclo politicos, assente na premissa da debilidade dos grandes partidos, valorizando as demais estruturas partidárias. Empenhava-se no patrocínio de novas fórmulas governativas de convergência partidária, conforme a estabelecida entre progressistas e regeneradores liberais, em 2 de Abril desse ano. No momento da escolha do responsável pelo governo, D. Carlos enveredava pela via menos provável: entre os dois líderes coligados - João Franco e José Luciano de Castro - o rei concedia a primazia do executivo ao primeiro, embora de menor expressão numérica partidária.

Esta característica não iludia outras como a capacidade de mobilização demonstrada por João Franco, entretanto concretizada, e o projecto protagonizado pelo lider regenerador liberal, de cariz modernizante nos conteúdos programáticos e nos moldes discursivos. Observe-se os propósitos de Franco em dilatar a base social de apoio dos regeneradores liberais, na tentativa de quebrar o elitismo característico dos congéneres partidários e actuar junto das camadas populacionais onde o Partido Republicano Português recrutava apoiantes e seguidores.

Considerada nesta perspectiva, a solidariedade gerada entre o chefe do estado e o líder do governo do período subsequente, até Fevereiro de 1908, constituía a síntese natural no plano político das necessidades do país e das vontades da nação, particularmente visível na fórmula como D. Carlos secundou a experiência governativa de João Franco, enquanto responsável de governo constitucional, e posteriormente no recurso à ditadura. Em ambos os casos, D. Carlos afiançava o franquismo como o meio adequado de administrar o país, uma certeza adquirida no malogro sucessivo dos governos constituídos pelos grandes partidos no quadro do rotativismo, de maior premência se considerada a ascensão da oposição anti-monárquica em especial do Partido Republicano Português.

O novo executivo era empossado a 19 de Maio de 1906 contudo, a 29 de Setembro, a coligação governativa apresentava grandes debilidades. Em Outubro seguinte, a oposição republicana criticava as orientações governamentais e a composição do gabinete. O governo subsistia alentado na moralização pública e, em Novembro, dava cumprimento ao plano de saneamento das contas públicas, dando origem à denominada questão dos adiantamentos à Casa Real. A temática resultava da insuficiência dos recursos financeiros adstrictos à Casa de 
Bragança, penalizada pela não actualização dos valores durante a segunda metade do séc. XIX. Tratava-se de uma questão antiga, conhecida pelos partidos com responsabilidades governativas e inclusivamente do domínio público onde, não raras vezes, as carências do rei eram alvo de chacota. Porém, este momento foi aproveitado pela oposição anti-monárquica e, em particular, pelos deputados republicanos na câmara para um ataque acérrimo às instituições e aos partidos monárquicos responsáveis. Neste contexto, Afonso Costa desferiu críticas duras de cumplicidade ao presidente do Conselho nas práticas e aos instrumentos de resolução para corrigir o défice financeiro da Familia Real. Por outro lado, opunha-se à elevação dos valores da Lista Civil do rei, de 100 para 160 contos $^{92}$.

A questão dos adiantamentos à Casa Real repercutiu-se em perdas sucessivas para o governo, para as estruturas partidárias monárquicas, para as instituições e, em última análise, para o rei: nas câmaras, as sessões conturbadas prolongaram-se durante o mês de Novembro e o nível de conflituosidade regrediu com a suspensão dos representantes republicanos. Fora do parlamento, a questão progredia sem controlo; a imprensa afecta ao Partido Republicano e à Dissidência Progressista não se coibiam de criticar os protagonistas, com ênfase para João Franco e o rei D. Carlos. O governo, por seu turno, reagia com uma lei da imprensa para refrear os ânimos da oposição, conhecida por "lei contra a imprensa". Em vez do decréscimo de animosidade, os fenómenos de contestação multiplicavam-se e atingiam novos segmentos, como a greve de estudantes de Coimbra, iniciada em Março de 1907. Consequentemente, D. Carlos acedia ao apelo de João Franco e, em 11 de Abril, decretava o encerramento das Câmaras cuja dissolução seria do domínio público em 10 de Maio seguinte.

D. Carlos via-se forçado a retomar parcialmente as práticas anteriores e João Franco enveredava por uma nova fase de governação, caracterizada pelos adversários de "à turca", iniciada por uma remodelação governamental. Robustecido o núcleo governativo, João Franco tentou um controlo apertado da imprensa com nova legislação: insistia-se na proibição de quaisquer escritos, desenhos ou impressos atentatórios da ordem pública. Os governadores civis passava a dispor de amplos poderes para efectuarem a suspensão de periódicos e decidirem sobre a natureza de publicações novas, sem intervenção das autoridades judiciais. No final de 1907, o cumprimento desta disposição conduzira à suspensão de nove periódicos, não exclusivamente republicanos, na capital, um padrão que se estendia à totalidade do território nacional.

O governo prestava especial atenção ao poder local: explicava-se assim a dissolução da Câmara Municipal de Lisboa, em 5 de Junho, acompanhada do adiamento das eleições municipais gerais em 14 de Outubro. Em 12 de Dezembro, o governo em ditadura anunciava a extinção das juntas gerais, das comissões distritais, das câmaras municipais e das juntas de paróquia do país, corpos administrativos substituídos por comissões administrativas de nomeação directa ou indirecta do poder central. A repressão fez-se sentir ainda no aumento das competências do Juízo Criminal e da Polícia Civil de Lisboa e no número crescente de detidos sem culpa formada. Os centros republicanos centraram

\footnotetext{
${ }^{92}$ Teresa Nunes, D. Carlos. O Diplomata, op. cit., pp. 74-81.
} 
muita da atenção das autoridades; proibidos de exercerem actividade politica, muitos viriam a ser encerrados.

O governo franquista procurava desanuviar as tensões através de reformas sociais, por exemplo a promoção dos vencimentos da função pública, dos sargentos e praças das Forças Armadas. Decretava o descanso semanal obrigatório, promulgava um regime de aposentação para os trabalhadores e desencadava uma campanha de obras públicas destinada à criação de postos de trabalho. No domínio da instrução, estabelecia preparação militar obrigatória, investia na construção de novos edifícios escolares e na reorganização do ensino público. Do ponto de vista económico e financeiro, o franquismo procurou alargar as receitas públicas sem prejuízo do recurso ao crédito para suportar as obras públicas projectadas para estimular a actividade económica. Esta, com predominância no sector primário, ocupou o executivo que procurou reduzir as áreas de plantação de vinha para eliminar a produção excedentária. Apostou ainda na instituição de novas zonas demarcadas e na procura de novos mercados externos, uma tendência de diversificação implementada desde o início do reinado ${ }^{93}$.

D. Carlos, atento à conjuntura interna, apoiava as transformações preconizadas pelo presidente do ministério, conforme referia em entrevista concedida a Joseph Galtier, jornalista do Le Temps, em Novembro de 1907. A 16 desse mês, o Diário Ilustrado divulgava as convicções régias sobre o ministério:"ao contrário das intenções que me atribuem, entendo mantê-lo. Estou muito satisfeito com ele. Isto vai muito bem. Há-de durar, é preciso que dure no interesse do país". Esta mensagem, originalmente destinada aos credores europeus do país, causavam impacto profundo nos grandes partidos monárquicos e nas estruturas contrárias à Monarquia Constitucional. Para Júlio Vilhena, então líder do Partido Regenerador, D. Carlos "já não é um rei, é um jornalista. Gosta da luta com os adversários, atacando-lhes os brios, a energia, o carácter (em francês), rindo-se e chacoteando deles. É ele que se atira à arena dos debates como audaz gladiador"94.

O Partido Republicano, por seu turno, beneficiava das adesões de duas figuras monárquicas relevantes: Augusto José da Cunha, antigo professor do rei com experiência ministerial, e Anselmo Braamcamp Freire, em repúdio ao atropelo do sistema parlamentar patrocinado pelo rei. Observava-se ainda uma alteração da estratégia política republicana: a erosão das instituições monárquicas, dentro e fora do contexto institucional, favorecia a tese de conquista do poder, em tempo breve, com recurso à violência.

Consequentemente, intensificava-se a produção artesanal de bombas, a dita "Artilharia Civil”, denominação dada à Carbonária, associação secreta formada por opositores à Monarquia recrutados entre as classes média e baixa da população urbana, particularmente expressiva em Lisboa. Sem exclusivismo político, a Carbonária agregava diferentes tendências ideológicas como anarquistas intervencionistas, socialistas e republicanos, numa época de ligação forte entre este último grupo e a Dissidência Progressista, conforme se

\footnotetext{
${ }^{93}$ Teresa Nunes, D. Carlos. O Diplomata, op. cit., pp. 82-84.

${ }^{94}$ Teresa Nunes, D. Carlos. O Diplomata, op. cit., pp. 85-90.
} 
comprovava na tentativa revolucionária frustrada de 28 de Janeiro de 1908 cuja liderança era compartilhada por Afonso Costa e José Maria de Alpoim. Desmantelada a conjura, o governo reforçava os instrumentos repressivos: em 31 de Janeiro, D. Carlos sancionava um novo enquadramento para os crimes contra a segurança do Estado, publicado sem delongas.

No dia seguinte, o rei reiterava a solidariedade com a solução repressiva do executivo e a Família Real regressava a Lisboa. À chegada, o Terreiro do Paço apresentava um ambiente de normalidade aparente: a avaliar pelo testemunho de António Cabral, muitos notáveis e poucos populares aguardavam o rei, correspondendo aos parâmetros de conduta comuns da população lisboeta. Esta acalmia justificava a ausência de medidas especiais de protecção à Família Real, vitimada por atentado no mesmo local do qual resultavam as mortes de D. Carlos e de D. Luís Filipe, o príncipe herdeiro ${ }^{95}$.

A continuidade da Monarquia Constitucional portuguesa era assegurada por D. Manuel, pelo filho segundo do Casal Real. Com uma imagem pública conotada com a fragilidade, o novel rei sofria da influência concertada de três factores essenciais: a juventude, a impreparação e a inexperiência política. Porém, as percepções sobre o jovem monarca, concebidas no contexto nacional e principalmente nas cortes europeias, reflectiam as impressões causadas pela reacção de Lisboa durante as exéquias de D. Carlos e D. Luís Filipe. Para espanto dos observadores e ou participantes estrangeiros das cerimónias, a capital portuguesa mobilizava-se em memória dos regicídas, os novos mártires da pátria, aos quais prestavam múltiplas demonstrações de apreço - romagens em memória, subscrições para auxilio dos órfaos. O silêncio do enterro do rei e principe constrastava com o entusiasmo fervilhante das procissões populares aos túmulos dos regicidas, no cemitério do Alto de São João ${ }^{96}$.

Segundo a visão de Carlos Malheiro Dias, "a República, desde que a bala de um executor suspendeu a vida do hércules loiro que a ameaçava com a sua energia combativa, era, dada a insignificância mental e o desprestígio moral da quase generalidade dos homens que serviam a Monarquia, um facto iminente, imposto por inúmeras circunstâncias que favoreciam o seu triunfo"97.

\section{CONSIDERAÇÕES FINAIS}

Entre 1880 e 1910, a Monarquia Constitucional portuguesa confrontou-se com um conjunto de dilemas tributários da modernização institucional, dos desafios da alteração do enquadramento político e partidário e, não menos relevantes, das mudanças substanciais verificadas na sociedade portuguesa. Entre essas mutações evidenciava-se o entendimento subordinado à imagem pública do Rei, conforme os cânones consagrados pela Carta Constitucional, de Abril de 1826, sucessivamente reformulados em 1852, em 1885 e em 1896. Fosse pela natureza das atribuições intrínsecas à figura régia, no âmbito dos poderes

\footnotetext{
${ }^{95}$ Teresa Nunes, Carlos Malheiro Dias. Um Monárquico entre dois Regimes, Lisboa, Caleidoscópio, 2009, pp. 8386.

${ }^{96}$ Rocha Martins, D.Manuel II. Memórias para a História do seu Reinado, I Vol. Lisboa, Ed. José Bastos, s.d., p. 93.

${ }^{97}$ Carlos Malheiro Dias, Do Desafio à Debandada. O Pesadelo, vol. I, Lisboa, Livraria Clássica, 1912, p. 16.
} 
legislativo, executivo e moderador, fosse pelas dinâmicas de projecção pública das formações partidárias surgidas a partir dos anos 70, do séc. XIX, fosse pelo efeito conjugado de ambas as premissas, o rei constitucional português adquiria uma centralidade inusitada no discurso politico das correntes oposicionistas aos governos em funções. Comummente caracterizado como incapacitado de agir segundo os preceitos constitucionais, durante a década de 80 , o monarca viu-se a braços com o Tricentenário Camoniano, em 1880, com o desenvolvimento da opinião pública nos perímetros urbanos e, concomitantemente, com os efeitos da degradação das condições de vida nos grandes aglomerados, associados à consolidação de uma corrente anti-monárquica caracterizada pela heterogeneidade ideológica e pela predisposição aos métodos de acção directa.

Porém, a D. Luís, em 1883-4, como a D. Carlos, em 1907, o espectro da campanha difamatória tendente à abdicação dos chefes de estado em favor dos primogénitos respectivos provinha de estruturas partidárias monárquicas para as quais o rei funcionava como um elemento de destabilização do regime constitucional, não como um garante da constitucionalidade. As pressões internacionais sobre o espaço colonial, mormente as disputas territoriais nos primórdios dos anos 90, propiciava uma ampla vaga de contestação antimonárquica, assente na correlação estreita entre os agressores da soberania nacional e os aliados da monarquia constitucional. Exponenciada, esta premissa axiomática produzia a primeira insurreição republicana em Portugal. O refluxo do movimento republicano, observado nos anos subsequentes devido à repressão monárquica, era ultrapassado no início do séc. XX.

Assim, a primeira década de Novecentos revelava-se paradoxal para a monarquia constitucional portuguesa: ao republicanismo alentado pela efervescência gradualmente revolucionária correspondia uma reconfiguração das forças partidárias monárquicas. O padrão de partidarização política da figura régia, ocorrido no reinado de D. Luís, era reproduzido durante as vigências de D. Carlos e mesmo de D. Manuel II, com violência redobrada, uma realidade explicada pela multiplicação dos agentes actuantes na descredibilização da figura régia e, por extensão da família real.

\section{BIBLIOGRAFÍA}

Acto Adicional à Carta Constitucional Julho de 1852.

Acto Adicional. Lei de 24 de Julho de 1885. Apenso à Carta Constitucional.

Acto Adicional à Carta Constitucional de 25 de Setembro de 1896

"A Revolução de Espanha e os Quatro Fuzilados de Numancia", Almanach do Trinta para 1884, V Ano, Lisboa, Tipografia Popular, 1882, p 22.

Azevedo, Guilherme de, "Crónica Ocidental". O Ocidente. Revista Ilustrada de Portugal e do Estrangeiro, ${ }^{\circ}$ 60, 15 de Junho de 1880, p. 102.

Carta Constitucional da Monarquia Portuguesa decretada e dada pelo Rei de Portugal e Algarves, D.Pedro do Brasil, aos 29 de Abril de 1826, Lisboa, Imprensa Régia, 1827

Braga, Teófilo, História de Camões, 3 vols, Porto, Imprensa Portuguesa, 1873. 

1873.

Braga, Teófilo, Os Novos Críticos de Camões, Porto, Imprensa Portuguesa,

Constituição Politica da Monarquia Portuguesa decretada pelas Cortes Gerais Extraordinárias e Constituintes reunidas em Lisboa, no Ano de 1821, Lisboa, Imprensa Nacional, 1822. 1838.

Constituição Politica da Monarquia Portuguesa, Lisboa, Imprensa Nacional,

Coruche, Visconde de, "Novo Partido Nacional e o Mal Cosmopolita", A Época, $\mathrm{n}^{\mathrm{o}} 727,5$ de Maio de 1889, p. 1.

"Crónica Ocidental", O Ocidente. Revista Ilustrada de Portugal e do Estrangeiro, n 84, 21 de Abril de 1881, pp. 89-90.

Diário das Cortes Constituintes, sessão no 10, 9 de Fevereiro de 1822, p. 136.

Dias, Carlos Malheiro, Do Desafio à Debandada. O Pesadelo, vol. I, Lisboa, Livraria Clássica, 1912.

Hamlet: drama em cinco actos. Tradução portuguesa de D. Luis I, Lisboa, Imprensa Nacional, 1877, $2^{\mathrm{a}}$ ed. em 1880.

Juromenha, Visconde de, Obras de Luís de Camões: precedidas de um ensaio biográfico no qual se relatam alguns factos da sua vida aumentadas com algumas composições inéditas do Poeta, 6 vols, Lisboa, Imprensa Nacional, 1860-1869.

"Juízo do Ano", Almanach do Trinta para 1881, II Ano, Lisboa, Tipografia Popular, 1880, pp. 52-53.

"Juízo do Ano", Almanach do Trinta para 1882, III Ano, Lisboa, Tipografia Popular, 1881, p. 141.

Leoni, Francisco Evaristo, Camões e os Lusiadas: ensaio histórico-crítico, Lisboa, A.M.Pereira, 1872.

Lobato, Gervásio, "Crónica Ocidental", O Ocidente. Revista Ilustrada de Portugal e do Estrangeiro, n 68, 15 de Outubro de 1880, p. 166.

Lobato, Gervásio, "Crónica Ocidental", O Ocidente. Revista Ilustrada de Portugal e do Estrangeiro, n 105, 21 de Novembro de 1881, p 257.

Lobato, Gervásio, "Crónica Ocidental", O Ocidente. Revista Ilustrada de Portugal e do Estrangeiros, $\mathrm{n}^{\circ}$ 74, 11 de Janeiro de 1881, p. 8.

Martins, Joaquim Pedro de Oliveira, Os Lusiadas. Ensaio sobre Camões e a sua obra em relação à sociedade portuguesa e ao movimento da Renascença, Porto, Imprensa Portuguesa, 1872.

Martins, Rocha, D.Manuel II. Memórias para a História do seu Reinado, I Vol., Lisboa, Ed. José Bastos, s.d.

Mercador de Veneza. Drama em cinco actos. Tradução de D. Luis, Lisboa, Imprensa Nacional, 1879.

O Ocidente. Revista Mustrada de Portugal e do Estrangeiro, $\mathrm{n}^{\circ}$ 80, 11 de Março de 1881 , p. 58.

O Ocidente, Revista Iustrada de Portugal e do Estrangeiro, $\mathrm{n}^{\circ} 110,11 \mathrm{de}$ Janeiro de 1882, pp. 10-18. 
"Os Fuzilados", Almanach do Trinta para 1884, V Ano, Lisboa, Tipografia Popular, 1882, p. 84-85.

“O Simãosinho Real”, Almanach do Trinta para 1884, V Ano, Lisboa, Tipografia Popular, 1882, p 102

Othelo, o mouro de Veneza de William Shakespeare: tragédia em cinco actos traduzida para português por D. Luís de Bragança, Lisboa, Imprensa Nacional, 1885.

Ricardo III. Drama histórico em cinco acto. Tradução de D. Luis I, Lisboa, Imprensa Nacional, 1880;

Schwalbach, Eduardo, À Lareira do Passado, Lisboa, Ed. Do Autor, 1944.

Teles, Basílio, Do Ultimatum ao 31 de Janeiro: esboço d'História politica, Porto, Ed. Autor, 1905.

Trindade Coelho, Manual Politico do Cidadão Português, Lisboa, Parceria A.M. Pereira, 1906.

Bibliografia Específica

Almeida, Pedro Tavares de, A Construção do Estado Liberal: Elite Politica $e$ Burocracia da Regeneração (1851-1890). Tese de doutoramento, Lisboa, Universidade Nova de Lisboa, 1995.

Bonifácio, Maria de Fátima, O Seculo XIX português, Lisboa, Instituto de Ciências Sociais, 2002.

Bonifácio, Maria de Fátima, A Segunda Ascensão e Queda de Costa Cabral 18471851, Lisboa, ICS, 2002.

Bonifácio, Maria de Fátima, Monarquia Constitucional 1807-1910, Alfragide, Texto, 2010.

Caetano, Marcelo, Constituições Portuguesas, $4^{\mathrm{a}}$ ed.. actualizada, Lisboa, Verbo, 1978.

David, Justino, A Formação do Espaço Económico Nacional, 2 vols, Lisboa, Vega, 1989.

Guilherme de Azevedo, Crónica Ocidental, coord. por Ernesto Rodrigues, Lisboa, Espera do Caos, 2016.

Hespanha, António Manuel, Guiando a Mão Invisivel. Direitos, Estado e Leis no Liberalismo Monárquico Português, Coimbra, Almedina, 2004

Homem, Amadeu Carvalho, A Propaganda Republicana (1870-1910), Coimbra, Coimbra Editora, 1990.

Lains, Pedro, A Economia Portuguesa no séc. XIX. Lisboa, INCM, 1995.

Leal, Ernesto Castro, Manifesto, Estatutos e Programas Republicanos Portugueses, Lisboa, INCM, 2014.

Macedo, Jorge Borges de, "Camões - Símbolo e Mito no séc. XIX Português: da erecção da estátua ao Trincentenário (1867-1880)", História de Portugal, Coord. por João Medina, vol. VIII, Alfragide, Ediclube, 1993, pp. 321-344.

Miranda, Jorge, As Constituições Portuguesas: 1822, 1838, 1911, 1933, 1974, Lisboa, Petrony, 1976. 
Nunes, Teresa, Maria da Fonte e Guerra Civil da Patuleia 1846-1847, Matosinhos, QuidNovi, 2008.

Nunes, Teresa, Fontes Pereira de Melo, Lisboa, Planeta D'Agostini, 2004.

Nunes, Teresa, D. Carlos. O Diplomata 1889-1908, Matosinhos, Academia Portuguesa de História/QuidNovi, 2009.

Nunes, Teresa, Carlos Malheiro Dias. Um Monárquico entre Dois Regimes, Lisboa, Caleidoscópio, 2009.

Nunes, Teresa "A Espanha na Diplomacia Comercial Portuguesa na Segunda Metade do Séc. XIX e o Tratado de Comércio e Navegação de 1893", História [online]. 2017, vol.36, e14. Epub Aug 17, 2017. ISSN 1980-4369. http://dx.doi.org/10.1590/1980-436920170000000014.

Pereira, António Manuel, As Constituições Politicas Portuguesas, Porto, A.M. Pereira, 1961.

Pereira, Miriam Halpern, Livre-Câmbio e Desenvolvimento Económico. Portugal na segunda metade do séc. XIX, Lisboa, Cosmos, 1971.

Pereira, Miriam Halpern, A Politica Portuguesa de Emigração (1850-1930), Lisboa, A Regra do Jogo, 1981.

Pina, Ana Maria, De Rousseau ao imaginário da Revolução de 1820, Lisboa, Instituto Nacional de Investigação Científica, 1988.

Rodrigues, Teresa, História da População Portuguesa. Das longas permanências à conquista da modernidade, Porto, Cepese/Afrontamento, 2009.

Silveira, Luís Espinha da, Fernandes, Paulo Jorge, D. Luis I, Rio de Mouro, Temas e Debates, 2009.

Vaz, Maria João, Crime e Sociedade: Portugal na segunda metade do séc. XIX, Oeiras, Celta, 1998.

Ventura, António, Anarquistas, Republicanos e Socialistas em Portugal. As Convergências Possiveis (1892-1910), Lisboa, Cosmos, 2000.

Enviado el (Submission Date): 29/03/2019

Aceptado el (Acceptance Date): 3/05/2019 